\title{
Article
}

\section{Preliminary Study of Seed Production of the Micronesian Mud Crab Scylla serrata (Crustacea: Portunidae) in Korea}

\author{
Soon Kil Yi ${ }^{*}$, So-Gwang Lee ${ }^{2}$, and Jeong-Mee Lee ${ }^{2}$ \\ ${ }^{l}$ Marine Living Resources Research Department, KORDI \\ Ansan P.O. Box 29, Seoul 425-600, Korea \\ ${ }^{2}$ Fisheries Resources Research Institute, Gyeongsangnam-do \\ Tongyeong 650-947, Korea
}

\begin{abstract}
Seventeen females of the mud crab Scylla serrata, from the State of Kosrae, Micronesia, were transported to the Fisheries Resources Research Institute, Gyeongsangnam-do, in oxygen-filled plastic bags. After acclimatization to a $30^{\circ} \mathrm{C}$ holding temperature, nine females were selected for seed production trials. Spawning was hastened using eyestalk ablations; however, this may not be required in commercialscale mud crab seed production. Primary spawning produced an average of 2.4 million hatched larvae, whereas secondary spawning produced 0.4 million. About 10 days elapsed between spawning and hatching and 30 days between hatching and crablet. Mass mortalities up to $90 \%$ were observed between stages zoea 1 and zoea 2 in every trial. The highest survival rate from zoea 1 to crablet was estimated at $0.25 \%$. Most commercial shrimp hatcheries in Korea are equipped with almost all necessary facilities and could be converted easily to mud crab hatcheries, able to run three to four times per year using hatchery technologies developed for blue crabs and Chinese mitten crabs.
\end{abstract}

Key words : mud crab, eyestalk ablation, seed production, crablet, Micronesia

\section{Introduction}

Mud crabs of the genus Scylla are important marine resources for islanders and coastal dwellers throughout the Pacific and Indian Oceans. Four species of mud crabs, Sylla serrata, S. paramamosain, S. olivacea, and $S$. tranquebarica, are commercially important. Among these, $S$. serrata has the highest market value. It is distributed widely from the eastern coast of Africa to the southeastern coast of China, and from the middle part of the Australian coast to the southern part of the Japanese coast. Kim (1973) has reported the presence of S. serrata at Geoje-do, on the southern coast of Korea, on the basis of a young specimen caught by Kajima (1941). However, recent studies (Hong 2006) have suggested that the mud crabs distributed in Korea are not S. serrata but S. paramamosain, sensu Keenan et al. (1998).

\footnotetext{
*Corresponding author. E-mail : skyi@kordi.re.kr
}

In 2007, the annual harvest by catch and aquaculture of mud crabs, which are associated with mangrove complexes, reached about 32,000 and 118,000 tons, respectively (FAO 2009). Demand for mud crabs in international markets is increasing steadily (SPC 2009); however, the supply of mud crabs destined for international markets is decreasing in most Pacific nations due to significant domestic demands. Studies of the commercial production of $S$. serrata crablets (seed crabs) have been ongoing for four decades (Ong 1964; Brick 1974; Hill 1974; Chen 1976; Heasman and Fielder 1983; Zeng and Li 1992; William et al. 1999; Nurdiani and Zeng 2007). However, a commercially viable larval rearing protocol has yet to be established (Ruscoe et al. 2004; Zeng and Rabbani 2005). Present mud crab aquaculture relies merely on the growout and fattening of wild juvenile crabs in domestic facilities. This practice will eventually threaten natural stocks, and the securing of juvenile crabs will become increasingly difficult. Some progress in the sustainable seed production of mud crabs has been achieved in 
Australia, China and the Philippines, but to date, commercial scale aquaculture is still not viable.

However, $S$. serrata grows very fast in captive conditions. Crablets weighing about $10 \mathrm{~g}$ (carapace width: 4 to $5 \mathrm{~cm}$ ) can grow to $400 \mathrm{~g}$ (carapace width: $15 \mathrm{~cm}$ ), which is a marketable size, within 6 months with an optimum temperature regimen and an adequate food supply (Prinpanapong and Youngwanichsaed 1991, Hong 1999). Thus, mud crabs are potentially an excellent new aquaculture species during the warm season in Korea that would ease the demands on blue crabs and provide an alternative to the importation of high-value crustaceans such as king crab, lobster, and crayfish.

The major objective of this study is to provide general information on the seed production of $S$. serrata, which is essential for the establishment of a mud crab aquaculture industry in Korea. The study was focused on the sequence of larval development in the crab.

\section{Materials and methods}

\section{Collection and transportation of mother crabs}

Females of the mud crabs, Scylla serrata were caught by hand from a mangrove swamp in Utwa Village, Kosrae, Federated States of Micronesia (Fig. 1, Plate I-1) from August 4 to 6, 2006, and kept in a concrete tank with shelters. In the evening of August 7, 17 of the most active crabs with carapace widths exceeding $12 \mathrm{~cm}$ were chosen as the brood stock, and each of them was put into a mesh bag after washing and kept in a semi-soaked condition overnight. In the morning of August 8, each mesh bag was put into a paper bag before being placed in a $40-\mathrm{L}$ oxygen bag, to eliminate completely the possibility of the crabs puncturing the oxygen bags. Then, a wet towel was put

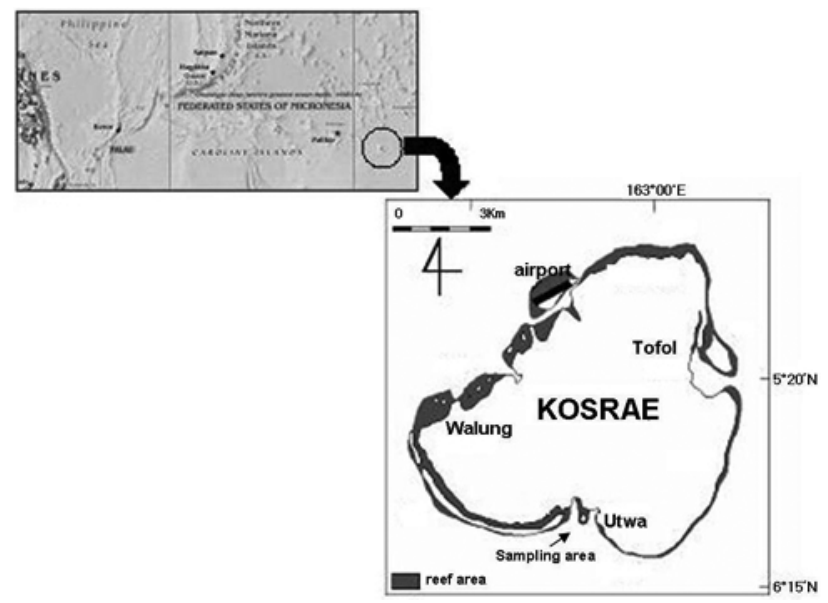

Fig. 1. Collection site of $S$. serrata in Kosrae, FSM. into each oxygen bag to maintain the moisture level, and the bag was filled with pure oxygen (Plate I-2). Three oxygen bags were placed together into an insulated Styrofoam box with some gel ice packs and transported to Incheon Airport by air. Upon arrival at the airport early in the morning on August 9, the mesh bags were removed and soaked in seawater before being placed into a carton with breathing holes. These were then transported to the Fisheries Resources Research Institute (FRRI), in Gyeongsangnam-do. Of the 17 crabs introduced to Korea, one died and six lost one or two appendages. The total process took about 30 hours and the crabs were kept in the oxygen bags for about 23 hours.

\section{Acclimatization and spawning}

Upon arrival at FRRI, each crab was put in a plastic basket $(42 \times 65 \times 35 \mathrm{~cm})$ and placed in a concrete tank $(5 \times 5 \times 1 \mathrm{~m})$ with filtered seawater supply nozzles for each plastic basket. Seawater was pumped from coastal waters of the FRRI and passed through a sand and active-carbon filter. Salinity was regulated at 34 psu using natural salt to provide the crabs with salinity conditions similar to those of where they were collected.

Holding water was disinfected using ultraviolet light and was supplied through the nozzles to the baskets. The initial water temperature was set to $26^{\circ} \mathrm{C}$ in accordance with the local air temperature during ground transportation. Water temperature was then increased by $1{ }^{\circ} \mathrm{C}$ per day until it reached $30^{\circ} \mathrm{C}$, such that the basic environmental conditions were equal to those of the original habitat of the crabs. Once the predesignated temperature was reached on August 13, the nine most active crabs were chosen, and their ovarian maturity was determined by examining, in the dark by using a flashlight, the contours of their ovaries. The carapace cavity is filled by an ovarian mass in fully matured females and cannot be penetrated by light from a flashlight. Females with ovarian contours exceeding three quarters of their carapace width were considered to be mature, whereas those with ovarian contours exceeding three fifths, but not exceeding three quarters, of the width were considered premature. Six mature and three premature females were identified, and these were fed raw fish twice a day until spawning. After two hours for feeding, the uneaten food was removed from the tanks.

\section{Induced spawning}

Among the six mature females, three were randomly selected and the left eyestalk of one individual was ablated on August 13. The other two individuals underwent eyestalk 
ablation on the following day. Before placing each female crab into a spawning container $(130 \times 85 \times 50 \mathrm{~cm})$, fine sand was layered into the containers, for a sediment depth of $15 \mathrm{~cm}$. Spawning containers were put into a 20-ton concrete tank $(10 \times 10 \times 2 \mathrm{~m})$. The water level in the tank was maintained at $40 \mathrm{~cm}$ and the water temperature was maintained near to $30^{\circ} \mathrm{C}$ using a thermostatic heat pump. Filtered seawater was supplied to each container through a pipeline laid on the tank wall. Water exchange rates in the tanks and containers were 4 and 10 times per day, respectively. In this manner, the water temperature in each container was maintained at $29.6 \pm 0.5^{\circ} \mathrm{C}$ during the study.

The crabs were checked every day and spawners were collected and put into new containers, as described above. A few berried eggs were dissected daily using forceps, and their embryonic development was observed under a stereomicroscope.

\section{Hatching and larval nursing}

Eight days after spawning, when the color of berried eggs changed from yellow to dark brown, the crabs were moved into the hatching tank $(5 \times 5 \times 1 \mathrm{~m})$. The water depth in the tank was first maintained at $50 \mathrm{~cm}$ and increased to $1 \mathrm{~m}$ as hatching approached. Just before hatching, as determined by active movement of eyed embryos (Plate I5), Nannocropsis oculata was added (for a total of 106 cells $/ \mathrm{m} l$ ) and the oxygen concentration was maintained at saturation with a liquid oxygen supply and vigorous aeration.

Hatching occurred at night. The total number of hatched larvae was determined by counting the number of larvae in five $10 \mathrm{~m} l$ subsamples which were taken from different parts of the hatching tank under dark conditions. Then, using a siphon, about one million floating larvae were transferred into a nursing tank $(5 \times 5 \times 1 \mathrm{~m})$ with a flow

\section{Plate I}

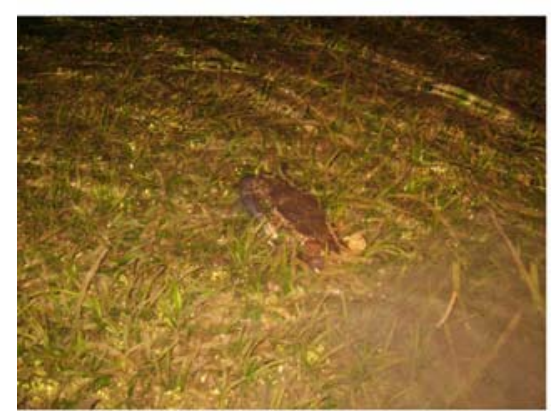

1. S. serrata in a feeding ground at night.

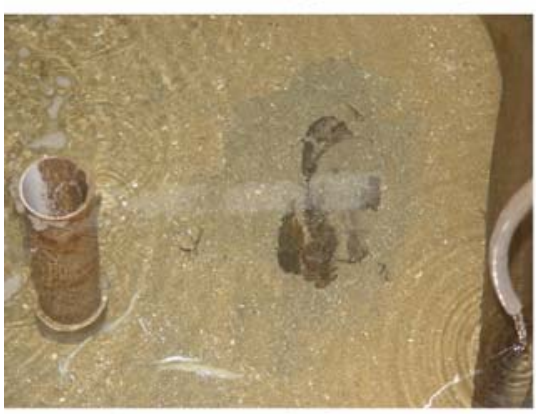

3. Spawning posture of a female $S$. serrata.

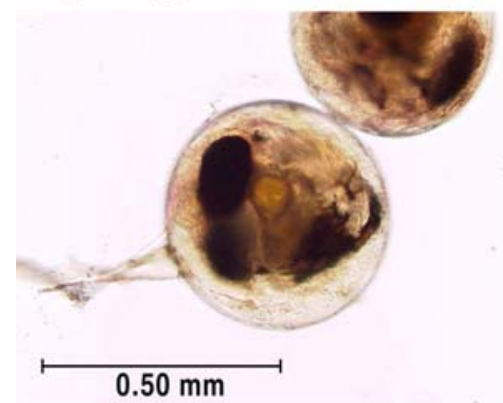

5. Eyed eggs of S. serrata, 10 days after spawning.

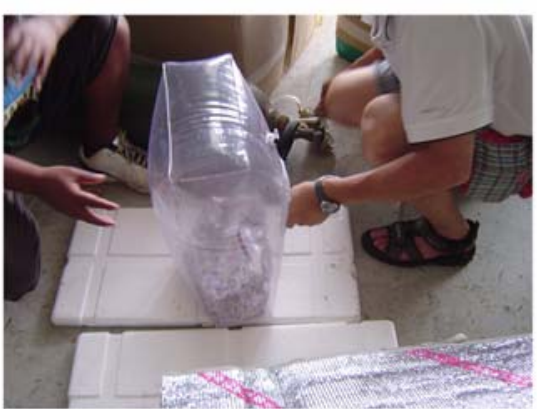

2. Packing a female $S$. serrata into an oxygen bag.

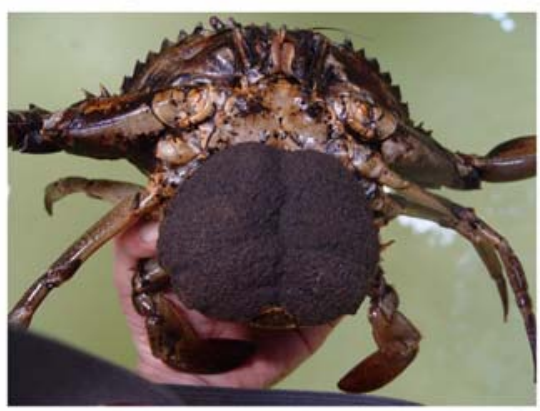

4. A berried $S$. serrata, close to the time of hatching.

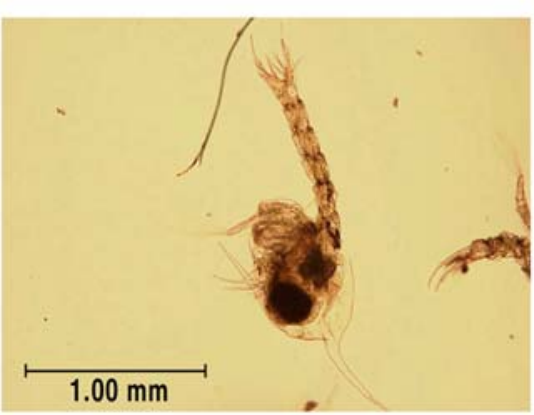

6. A zoea 1 stage larva of $S$. serrata. 
through water supply system. The tank was conditioned with $10^{6}$ cells $/ \mathrm{m} l$ of $N$. oculata a day to provide food to rotifers and to keep the water quality stable. The density of $N$. oculara was maintained until the larvae entered the megalopa stage. Water circulation rates in the nursing tanks were one and two times per day until the zoea 5 and megalopa stages, respectively.

Hatched larvae were fed with DHA-enriched rotifers until the zoea 5 stage. Commercial compound shrimp diets were added, beginning at the zoea 2 stage, and DHAenriched Artemia nauplii were supplied beginning at the zoea 3 stage. Artemia nauplii and minced shellfish were provided from the megalopa stage. The density of live feed in the nursing tanks was adjusted four times a day, to 25 individuals $/ \mathrm{m} l$ for the rotifers and 2 to 3 individuals $/ \mathrm{m} l$

\section{Plate II}

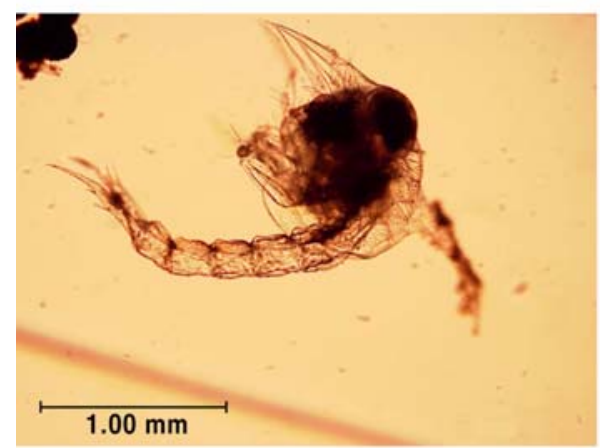

1. A zoea 2 stage larva of $S$. serrata.

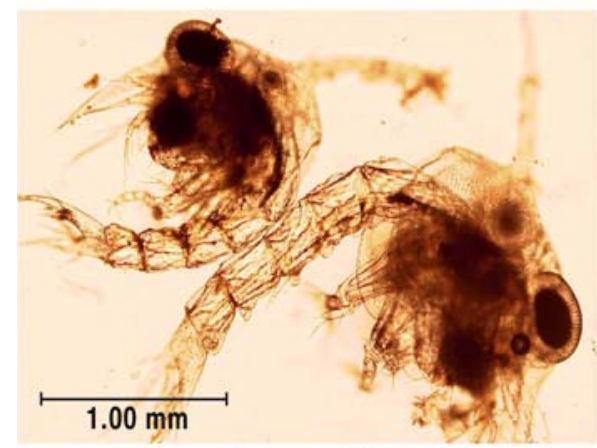

3. Zoea 4 stage larvae of $S$. serrata.

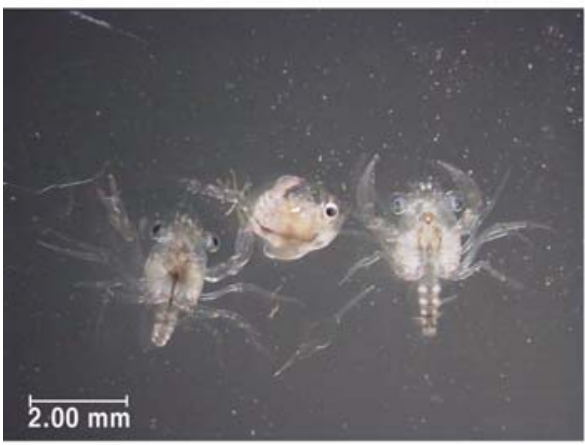

5. Megalopa larvae of $S$. serrata. for the Artemia nauplii. Once a day, in the morning, about $10 \%$ of the nursing-tank water was removed through a siphon from the bottom of each nursing tank to remove dead larvae and food remnants.

At the end of the zoea 5 stage, plastic shade films and $0.5-\mathrm{mm}$ net pans $(30 \times 50 \mathrm{~cm})$ were placed in nursing tanks to prevent cannibalism.

\section{Results}

\section{Spawning and berring}

Near the time of spawning, mature female crabs hollowed the substrate and dug a shallow divot (Plate I-3) for ease of berring (attachment of spawned eggs to pleopods). Spawning was conducted during dark periods and berring

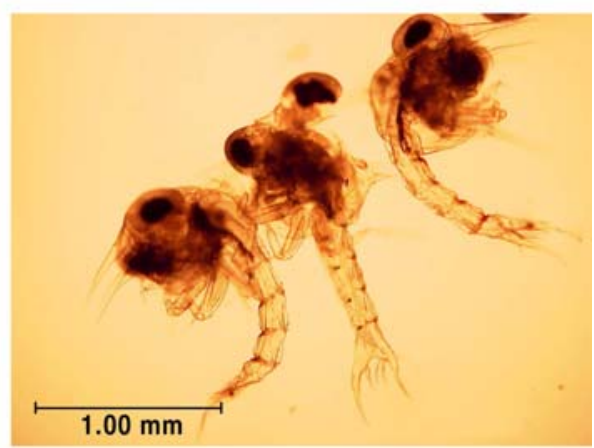

2. Zoea 3 stage larvae of $S$. serrata.

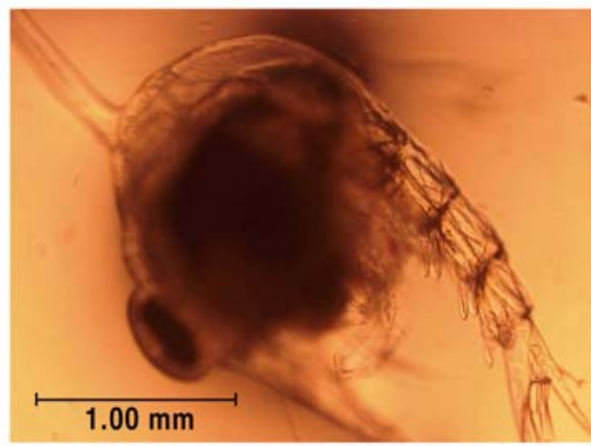

4. A zoea 5 stage larva of $S$. serrata.

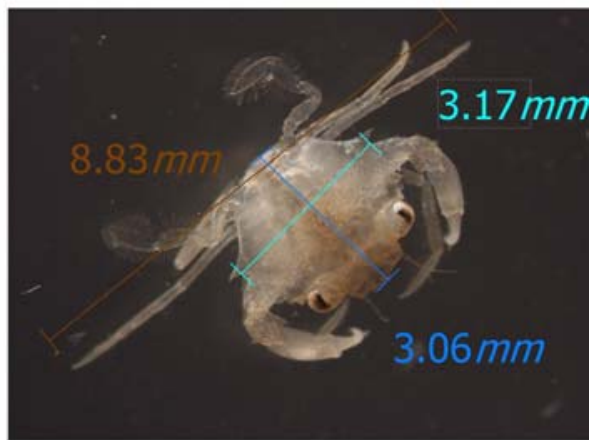

6. A crab 1 stage of $S$. serrata. 
Table 1. Spawning of $S$. serrata introduced from Kosrae, FSM (2006)

\begin{tabular}{|c|c|c|c|c|c|c|}
\hline \multirow{2}{*}{ No. } & \multirow{2}{*}{$\begin{array}{l}\text { Physical } \\
\text { condition }\end{array}$} & \multirow{2}{*}{ Maturity* } & \multirow{2}{*}{$\begin{array}{l}\text { Eyestalk } \\
\text { ablation }\end{array}$} & \multicolumn{2}{|c|}{ Spawning } & \multirow{2}{*}{ Berring } \\
\hline & & & & 1st & 2nd ${ }^{* *}$ & \\
\hline 1 & -rwl1 & $>3 / 4$ & Aug. 13 & Sept. 2 & & normal \\
\hline 2 & normal & $>3 / 4$ & Aug. 14 & Sept. 2 & & normal \\
\hline 3 & normal & $>3 / 4$ & Aug. 14 & Sept. 2 & Oct. 22 & normal \\
\hline 4 & -rcp & $>3 / 4$ & none & Sept. 5 & Oct. 30 & normal \\
\hline 5 & normal & $>3 / 4$ & none & Sept. 10 & & normal \\
\hline 6 & normal & $>3 / 4$ & none & Sept. 18 & & died \\
\hline 7 & normal & $>3 / 5$ & none & Sept. 30 & & noraml \\
\hline 8 & normal & $>3 / 5$ & none & Oct. 4 & & normal \\
\hline 9 & normal & $>3 / 5$ & none & & & died \\
\hline
\end{tabular}

*: ovarian contour/carapace width, **: without extra eyestalk ablation, -rwl1: lost 1st walking leg, -rcp: lost right cheliped.

took place immediately. The three females with ablated eyestalks spawned 20 days after ablation, whereas two intact females spawned after 23 and 28 days of holding. One intact mature female spawned after 36 days of holding but was unable to berry and died. Two females, including one with an ablated eyestalk, conducted secondary spawning on the 50th and 55th day after primary spawning (Table 1). One premature female died without spawning, but the other two premature females spawned and berried successfully after 48 and 52 days of holding.

The average number of hatched larvae in a primary spawning event was about 2.4 million; that of a secondary spawning event was 0.4 million.

\section{Hatching and larval rearing}

Immediately after berring, the mud crabs' eggs were

Table 2. Hatching of $S$. serrata introduced from Kosrae, FSM (2006)

\begin{tabular}{ccccc}
\hline No. & $\begin{array}{c}\text { Spawning } \\
\text { date }\end{array}$ & $\begin{array}{c}\text { Hatching } \\
\text { date }\end{array}$ & $\begin{array}{c}\text { Incubation } \\
\text { period } \\
\text { (days) }\end{array}$ & $\begin{array}{c}\text { No. of } \\
\text { larvae } \\
\text { (million) }\end{array}$ \\
\hline $1,2,3$ & Sept. 2 & Sept. 13 & 11 & 2.5 \\
4 & Sept. 5 & Sept. 15 & 10 & 2.4 \\
5 & Sept. 10 & Sept. 19 & 9 & 2.4 \\
7 & Sept. 30 & Oct. 10 & 10 & 2.4 \\
8 & Oct. 4 & Oct. 14 & 10 & 2.4 \\
\hline
\end{tabular}

orange, gradually turning dark closer to hatching and becoming almost black by the time of hatching (Plate I-4). Eye spots became visible from day seven. The rotation of eyed embryos were observable from day 8; embryos rotated actively as hatching drew near (Plate I-5). A total of 10 to 11 days elapsed between berring and hatching at a temperature of $29.6 \pm 0.5^{\circ} \mathrm{C}$ in captivity, except for the crab that spawned on September 5, for which the interval was 9 days (Table 2).

Newly hatched mud crab larvae (zoea 1) were about 1.3 $\mathrm{mm}$ in length (Plate I-6). The first molt occurred two days after hatching and larvae became zoea 2 larvae (Plate II1). They then molted at intervals of about three days before becoming zoea 5 larvae (Plates II-2, -3, and -4 and Table 3). The average rate of increase in body length during the zoeal stage was about $30 \%$ per molt. Zoea 5 larvae molted to become megalopa larvae within 7 days (Plate II-5). The color of the megalopa larvae darkened gradually as the molt proceeded, and megalopa became young crabs within 7 days (Plate II-6). The average carapace width and height of the crab 1 stage was $3.2 \mathrm{~mm}$ and $3.1 \mathrm{~mm}$, respectively. The crab 1 stage needed two additional molts to become a crablet (seed crab) with carapace length exceeding $25 \mathrm{~mm}$. On average, it took about 30 days from the time of hatching to crablet emergence.

Mortality was about $90 \%$ between the zoea 1 and zoea

Table 3. Time requirements for the metamorphosis of $S$. serrata larvae

\begin{tabular}{lccccccccc}
\hline Stage $^{*}$ & $\mathbf{Z - 1}$ & $\mathbf{Z - 2}$ & $\mathbf{Z - 3}$ & $\mathbf{Z - 4}$ & $\mathbf{Z - 5}$ & Meg. & $\mathbf{C - 1}$ & $\mathbf{C - 2}$ & $\mathbf{C - 3}$ \\
\hline Size $(\mathrm{mm}) * *$ & 1.33 & 1.63 & 2.09 & 3.05 & 4.06 & 1.79 & 3.06 & 5.02 & 25.80 \\
Age (day) & 2 & 4 & 6 & 9 & 12 & 15 & 22 & 26 & 29 \\
\hline
\end{tabular}

*Z: zoea, Meg: megalopa, C: crab, **zoea stage: body length, Megalopa and crab: carapace width. 
2 stages and about $80 \%$ between zoea 2 and zoea 3 stages. After zoea 3, mortality dropped to around $50 \%$ for each molt. The highest survival rate from zoea 1 to crablet was $0.25 \%$ and about 2,500 crablets were produced. The possible survival rate, as estimated from the highest survival rate of each larval stage during the study, was $0.8 \%$

\section{Discussion}

Eyestalk ablation has been a classic method for promoting the molting and spawning of crustaceans since Panouse (1943) and has been widely used in commercial shrimp hatcheries owing to its effectiveness in inducing sexual maturity (Arnstein and Beard 1975; Brady and Lawrence 1992; Hansford and Marsden 1995; Mann et al. 1999; Millamera and Quinitio 2000; Zeng 2007). Ablation also affects many physiological processes in adults and developing larvae (Grossl and Knowton 2002). However, a female mud crab can retain spermatozoa delivered by a male in her seminal receptacles for up to several weeks and can use them to fertilize multiple clutches of eggs (Chen 1976). Thus, it seems that eyestalk ablation may not be required to promote sexual maturation, except when there is an urgent need for larvae, as noted by Mann et al. (1999).

Among the nine female crabs used in this study, seven produced normal batches of larvae and the average batch size was about 2.4 million. The true average fecundity of the crabs probably exceeds 2.5 million eggs, however, considering that eggs that had not hatched by midnight of the day of hatching were not counted in this study. Two cases of secondary spawning were observed, with small batch sizes of approximately 0.4 million larvae. These batch sizes were within the normal range for spawning (Mann et al. 1999; Quinito et al. 2001) but were too small to be of use in a commercial hatchery. This poor result seemed to be caused by human disturbances, an unfamiliar captive environment and poor nutrients, as pointed out by Zeng and Li (1999), Djunaidah et al. (2003) and Rabbani and Zeng (2005).

The elapsed time from spawning to hatching was slightly less than that found by Phelan and Grubert (2007) and Nghia et al. (2007), seemingly because of a slightly higher seawater temperature in this study. Pre-zoea larvae (Mann et al. 1999; Williams et al. 1999) were counted as zoea 1 larvae, and zoea 6 larvae (Zeng et al. 2004) were not observed in the present study.

Mortality between the zoea 1 and zoea 2 stages was
$90 \%$, dropping to $80 \%$ between the zoea 2 and zoea 3 stages. Mortality then dropped to $50 \%$ for the remaining molts. Such mass mortalities are not uncommon in the larval culture of crustaceans including S. serrata (Quinitio et al. 2001; Hamasaki et al. 2002). The density of live food and its nutritional quality (Li et al. 1999; Williams et al. 1999; Quinito et al. 2001) and temperature (Li et al. 1999; Hamasaki et al. 2002) are believed to be responsible for such mass mortality.

The present study was conducted to establish a hatchery protocol. Each experiment used the number of larvae of each developmental stage that could be easily accommodated. The highest survival rate from zoea-1 to crablet was $0.25 \%$, but the maximum survival rate, as estimated from the highest survival rate in each larval stage during the study, was $0.8 \%$.

Most commercial shrimp hatcheries in Korea are equipped with almost all necessary facilities for mud crab seed production and could be converted easily to mud crab hatcheries. Moreover, technologies developed for the blue crab, Portunus trituberculatus (Chang 2002; Kim 2006), and the Chinese mitten crab, Eriocheir sinensis (KORDI 1992, 1994), can also be applied to mud crab hatcheries. The above mentioned survival rate is a goal for future studies, and the recommended production scale for the first mud crab hatchery is about 100,000 crablets. At least three runs would be possible in a year and five mature females would be required for each trial.

\section{Acknowledgements}

This article is part of "A study on the development of marine biological resources in the southwest Pacific", sponsored by the Ministry of Maritime Affairs and Fisheries in 2007. The authors gratefully express appreciation to the Marine Ranching Research Division, KORDI, and FRRI, Gyeongsangnam-do for their kind permission to use their facilities and for their assistance during the study. Special appreciation is also extended to the staff of Marine Fisheries, Government of Kosrae, Federated States of Micronesia for assisting in the handling of mother crabs.

\section{References}

Arnstein DR, Beard TW (1975) Induced maturation of prawn Penaeus orientalis Kishinouyi in the laboratory by means of eyestalk removal. Aquaculture 5(4):411-412

Brady WA, Lawrence AL (1992) Reproduction on Penaeus 
species in captivity. In: Fast AW, Lester LJ (eds) Marine shrimp culture: principles and practices. Developement aquaculture and fisheries science, vol 23. Elsevier, Amsterdam, pp 3-100

Brick RW (1974) Effects of water quality, antibiotics, phytoplankton and food on survival and development of larvae of Scylla serrata (Crustacea: Portunidae). Aquaculture 3(3):231-244

Chang SN (2002) Aquaculture of marine algae and crustaceans. Samkwang, Seoul, 533 p (in Korean)

Chen TP (1976) Aquaculture practices in Taiwan. Fishing News Books Limited, Long Garden Walk, Farnham, Surrey, $162 \mathrm{p}$

Djunaidah IS, Wille M, Kontara EK, Sorgeloos P (2003) Reproductive performance and offspring quality in mud crab (Scylla paramamosain) broodstock fed different diets. Aquacult Int 11(1-2):3-15

FAO (2008) Species fact sheets. Scylla serrata (null, 2001). FAO Species identification and data program. Text and table on the internet. http://www.fao.org/fishery/species/ 2637. Accessed 5 Mar 2009

Grossl PS, Knowlton RE (2002) Morphological Variations Among Larval-Postlarval Intermediates Produced by Eyestalk Ablation in the Snapping Shrimp Alpheus heterochaelis Say. Biol Bull 202(1):43-52

Hamasaki K, Suprayudi MA, Takeuchi T (2002) Mass mortality during metamorphosis to megalops in the seed production and mud carb Scylla serrata (Crustacea, Decapoda, Portunidae). Fish Sci 68(6): 1226-1232

Hansford SW, Marsden GE (1995) Temporal variation in egg and larval productivity of eyestalk ablated spawners of the prawn Penaeus monodon from Cook Bay, Australia. J World Aquacult Soc 26(4):396-405

Heasman MP, Fielder DR (1983) Laboratory spawning and mass rearing of the mangrove crab, Scylla serrata (Forsskal), from first zoea to first carb stage. Aquaculture 34(3-4):303-316

Hill BJ (1974) Salinity and temperature tolerance of the zoea of the portunid crab Scylla serrata. Mar Biol 25(1):21-24

Hong DD (1999) Description of mud crab (Scylla spp.) culture methods in Vietnam. In: Keenan CP, Blackshaw A (eds) Mud crab aquaculture and biology. Proceedings of an international scientific forum held in Darwin, Australia, 21-24 April, pp 67-71

Hong SY (2006) Marine invertebrates in Korean Coasts. Academy Press, Seoul, 479 p (in Korean)

Kajima T (1941) Studies on the decapod crustaceans of Chosen, Part I. Crabs Fisher Soc Chosen. Cited by Kim HS (1973). In: Illustrated encyclopedia of fauna \& flora of Korea. vol 14, Anomura-Brachyura. Ministry of Education, Seoul, p 299 (in Korean)

Keenan CP, Davie PJF, Mann DL (1998) A revision of the genus Scylla de Haan, 1833 (Crustacea: Decapoda: Brachyura: Portunidae). Raffles Bull Zool 46(1):217-245

Kim HS (1973) Illustrated encyclopedia of fauna \& flora of
Korea. vol 14. Anomura- Brachyura. Samwhaseojuck, Seoul, 694 p (in Korean)

Kim YH (2006) Aquaculture of fisheries animal. Daekyung, Seoul, 339 p (in Korean)

KORDI (1992). Studies on the seed production technics for Chinese mitten crab, Eriocheir sinensis. Korea Ocean Research and Development Institute, BSPG00172-527-3, 165 p (in Korean)

KORDI (1994) Studies on the development of intermediate rearing techniques and the mass production of its commercial goods of Chinese mitten crab, Eriocheir sinensis. Korea Ocean Research and Development Institute, BSPG00427-706-3, 118 p (in Korean)

Li S, Zeng C, Tang H, Wang G, Lin Q (1999) Investigations into the reproductive and larval culture biology of the mud crab, Scylla paramamosain: A research overview. In: Keenan CP, Blackshaw A (eds) Mud crab aquaculture and biology. Proceedings of an international scientific forum held in Darwin, Australia, 21-24 April. pp 121-124

Mann D, Asakawa T, Blackshaw A (1999) Performance of mud crab Scylla serrata broodstock held at Bribie Island Aquaculture Research Center. In: Keenan CP, Blackshaw A (eds) Mud crab aquaculture and biology. Proceedings of an international scientific forum held in Darwin, Australia, 21-24 April, pp 101-105

Millamera OM, Quinitio E (2000) The effects of diets on reproductive performance of eyestalk ablated and intact mud crab Scylla serrata. Aquaculture 181(1-2):81-90

Nghia TT, Wille M, Binh TC, Tran C, Thanh HP, Van Danh N, Sorgeloos P (2007) Improved techniques for rearing mud crab Scylla paramamosain (Estampador 1949) larvae. Aquacult Res 38(14):1539-1553

Nurdiani R, Zeng C (2007) Effects of temperature and salinity on the survival and development of mud crab, Scylla serrata (Foraakal), larvae. Aquacult Res 38(14):15291538

Ong KS (1964) Early development stages of Scylla serrata Forskl (Crustacea Portunidae), reared in the laboratory. Proceedings of the Indo-Pacific Fisheries Council 11(2): 135-146

Panouse JB (1943) Influence de l'ablation du pedoncle oculaire sur la croissance de l'ovaire chez la crevette Leander serratus. Acad Sci Paris 217:553-555

Phelan M, Grubert M (2007) The life cycle of the mud crab. Fishnote 11:1-4

Prinpanapong S, Youngwanichsaed T (1991) Rearing of mud crab (Scylla serrata). In: Angell CA (eds) Report of the seminar on the mud crab culture and trade. Swat Thani, Thailand, 5-8 November, BOBP/REP/51, Bay of Bengal Program, India, pp 101-105

Quinitio ET, Parado-Estepa FD, Millamena OM, Rodriquez E, Borlongan E (2001) Seed Production of Mud Crab Scylla serrata juveniles. Asian Fish Sci 14(2):161-174

Rabbani AG, Zeng C (2005) Effects of tank colour on larval survival and development of mud crab Scylla ser- 
rata (Forskaal). Aquacult Res 36(11):1112-1119

Ruscoe IM, Williams GR, Shelley CC (2004) Limiting the use of rotifers to the first zoeal stage in mud crab (Scylla serrata Forskål) larval rearing. Aquaculture 231(1-4):517-527

Williams GR, Wood J, Dalliston B, Shelley CC, Kuo CM (1999) Mud crab (Scylla serrata) megalopa larvae exhibit high survial rates on Artemia-based diets. In: Keenan CP, Blackshaw A (eds) Mud crab aquaculture and biology. Proceedings of an international scientific forum held in Darwin, Australia, 21-24 April, pp 131140

Zeng C (2007) Induced out-of-season spawning of the mud crab, Scylla paramamosain (Estampador) and effects of temperature on embryo development. Aquacult Res 38(14):1478-1485

Zeng C, Li S (1992) Experimental ecology study on the larvae of the mud crab, Scylla serrata. I. Effects of diets on survival and development of larvae. Trans Chinese Crust Soc no.3, China Ocean Press, Bejing, pp 85-94 (in Chinese)

Zeng C, Li S (1999) Effects of density and different combinations of diets on survival, development, dry weight and chemical composition of Larvae of the mud crab Scylla paramamosain. In: Keenan CP, Blackshaw A (eds) Mud crab aquaculture and biology. Proceedings of an international scientific forum held in Darwin, Australia, 21-24 April, pp 159-166

Zeng C, Li S, Zeng H (2004) Occurrence of additional Zoea-VI larvae in the mud crab, Scylla paramamosain (Estampador), reared in the laboratory. Hydrobiologia 529(1):49-58

Received Mar. 30, 2009

Revised Jun. 2, 2009

Accepted Aug. 21, 2009 